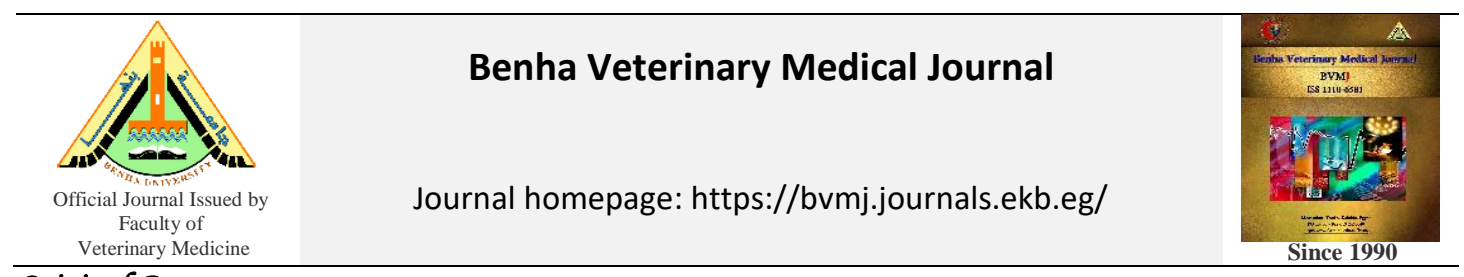

Original Paper

\title{
Bacteriological studies on Aeromonas and pseudomonas species in Nile tilapia (Oreochromis niloticus)
}

Ashraf A. Abd El-Tawab, Fatma El Hofy, Aya Ahmed

Bacteriology, Immunology and Mycology Department, Faculty of Veterinary Medicine, Benha University, Egypt.

\begin{tabular}{|c|c|}
\hline ARTICLE INFO & ABSTRACT \\
\hline $\begin{array}{l}\text { Keywords } \\
\text { Aeromonas } \\
\text { Bacteriological } \\
\text { Fish } \\
\text { Pseudomonas } \\
\text { Sensitivity tests. } \\
\text { Received 23/08/2019 } \\
\text { Accepted 03/11/2019 } \\
\text { Available On-Line } \\
\text { 12/05/2020 }\end{array}$ & $\begin{array}{l}\text { The present study was conducted on } 250 \text { diseased Nile tilapia (Oreochromis niloticus) of } \\
\text { various sizes collected from different fish markets at Kaliobia Governorate, Egypt, during the } \\
\text { period from May } 2017 \text { to January } 2019 \text { for inspection of Aeromonas and Pseudomonas strains. } \\
\text { Samples were collected from apparently pathognomonic lesions in muscle, liver, kidney, } \\
\text { intestine and spleen for bacteriological examination. The results revealed that, } 161 \text { Aeromonas } \\
\text { and Pseudomonas species; } 118 \text { Aeromonas }(73.3 \%) \text { and } 43 \text { Pseudomonas species ( } 26.7 \% \text { ) were } \\
\text { isolated mostly from } 50 \text { muscle lesion samples followed by } 41 \text { liver, } 35 \text { kidney, } 32 \text { intestine } \\
\text { and } 3 \text { spleen lesion samples. Aeromonas strains were highly sensitive to meropenem followed } \\
\text { by ciprofloxacin, norfloxacin, gentamycin and florphenicol. Meanwhile, they were highly } \\
\text { resistant for ampicillin and methicillin followed by oxacillin, penicillin-G, amoxicillin, } \\
\text { cefotaxime, oxytetracycline and streptomycin. In addition, Pseudomonas strains were highly } \\
\text { sensitive to meropenem followed by gentamycin, norfloxacin, ciprofloxacin and florphenicol. } \\
\text { In contrast, they were highly resistant for ampicillin, methicillin and penicillin-G followed by } \\
\text { amoxicillin, oxacillin and cefotaxime. }\end{array}$ \\
\hline
\end{tabular}

\section{INTRODUCTION}

Fish diseases due to bacterial infections mainly, Aeromonas and Pseudomonas species were considered the main causes of diseases including ulcerative syndrome leading to high mortalities also can be a problem for human consumers and high economic losses in Egypt (Abdel-Hadi et al., 2008; Shayo et al., 2012 and Hanna et al., 2014).

Members of the Aeromonas and Pseudomonas, are Gramnegative rods, either straight or curved facultative anaerobes, catalase-positive and most are motile by polar flagella. Their nutritional requirements are very simple and most grow on common laboratory media. They are widespread in freshwater, sewage, soil and their numbers rise with the amount of organic matter present (Markey et al., 2013). Aeromonads produce extracellular enzymes (haemolysins, lipases, proteases, $\beta$-lactamases, amylases, chitinases and nucleases) involved in their ecology, survival and pathogenicity (Stratev et al., 2015). In addition, the pathogenicity of $A$. hydrophila strains have been linked to some virulence factors produced by them including structural features associated with adhesion, cell invasion, resistance to phagocytosis as well as extracellular factors such as aerolysin, a pore-forming toxin, which is cytolytic and enterotoxin genie (Chopra and Houston 1999; Rabaan et al., 2001 ).

Pseudomonas (Ps.) aeruginosa and Ps. fluorescens are considered problematic pathogens as they possess cell- associated virulence factors such as (pili, flagella, lipopolysaccharide and alginate/biofilm). They also produces a number of extracellular products such as protein exotoxin A, proteases, type III secretion system exoenzymes, rhamnolipid, haemolysin with lecithinase activity; elastase (las B and las A), siderophores (pyochelin, pyocyanin, and pyoverdine by $P s$. aeruginosa and thioquinolobactin by Ps. fluorescens) and phospholipase C. (Mavrodi et al., 2001; Markey et al., 2013). These virulence factors play a role in disease pathogenesis.

As Aeromonas and Pseudomonas are considered one of the most important fish pathogens and can be a problem for human consumers too, the present study was conducted to throw light over their infection in freshwater fish, Niletilapia (O. niloticus).

\section{MATERIAL AND METHODS}

2.1. Samples collection:

250 diseased Nile tilapia (O. niloticus) of various sizes were collected from different fish markets at Kaliobia Governorate, Egypt, during the period from May 2017 to January 2019 for bacteriological examination of Aeromonas and Pseudomonas

2.2. Clinical and postmortem examinations It was performed using the method described by Schaperdaus et al. (1992).

\subsection{Bacteriological examination}

* Corresponding author: Prof. Ashraf A. Abd El-Tawab. Bacteriology, Immunology and Mycology Department, Faculty of Veterinary Medicine, Benha University, Egypt. 


\subsubsection{Sampling:}

Under complete aseptic conditions 445 samples were collected from apparently pathognomonic lesions in muscle, liver, kidney, intestine and spleen by a number of 139,118 , 99,70 and 19 , respectively.

\subsubsection{Isolation and identification of suspected Aeromonas and Pseudomonas species:}

The surface of lesions was smeared by hot spatula, then a sterilized loopful and inoculated onto Tryptone soya broth and incubated aerobically at $28{ }^{\circ} \mathrm{C}$ for 18 hours. A loopful from incubated Tryptone soya broth was streaked onto Tryptone soya agar and MacConkey's agar plates and incubated for 18 hours at $28{ }^{\circ} \mathrm{C}$. The pale colonies on MacConkey's agar and yellowish or creamy in color colonies on Tryptone soya agar were picked up and the following tests (Oxidase test and Catalase test) were performed.

The purified colonies were morphologically identified by Gram stain and biochemical tests (Quinn et al., 2002; Austin and Austin, 2007; Markey et al., 2013). The suspected colonies (that gave Oxidase +ve and Catalase +ve) were taken and cultivated on the following media: Aeromonas base agar; Rimler- Shotts agar (R.S.), Eosin methylene blue agar (EMB), Brilliant green agar, XLD agar, Pseudomonas agar and Pseudomonas Cetrimide agar then incubated for another 18 hours at $25{ }^{\circ} \mathrm{C}$ and $28^{\circ} \mathrm{C}$. Suspected colonies were kept in Semi-solid nutrient agar. Moreover, the in vitro sensitivity test was done en for each isolated bacteria to study its anti-microbial sensitivity according to Koneman et al. (1997).

\section{RESULTS}

The results of bacteriological examination of examined fish and in- vitro sensitivity tests for isolated strains were tabulated in tables (1-5).

The clinical examination of the studied fish showed irregular redness all over the fish body especially at the ventral part of abdomen, base of the fins, loss of fin membrane and sometimes loss of fin rays with grey patches at the tip of them (fins rot), and around the anal opening. Others showed eye cloudiness, detached scales, skin ulceration and abdominal distention. Internally, abdominal dropsy with reddish ascetic exudates and congestion of internal organs were observed. Congested intestine that sometimes filled with yellow mucous like materials was noticed. The infected fish showed abdominal dropsy with reddish ascetic exudates, liver paleness and enlarged in some fish and congested with gray patches in other fishes; congested kidneys; congested and enlarged spleen and congested intestine that sometimes filled with yellow exudates like materials in some fish.

The recovered Aeromonas isolates in the present study were Gram-negative, straight rods with round end, noncapsulated, non-sporulated. Moreover, they showed yellow to creamy colonies on Tryptone soya agar, pale colonies, and become pink on MacConkey's agar media. On RimlerShotts medium (R.S) they produced yellow convex colonies; on Aeromonas agar they gave green colonies darker in center than emerging. Only A. hydrophila strains gave violet to metallic green sheen colonies on EMB media due to lactose utilization, they gave yellow colonies on Thiosulphate- citrate-bile-sucrose (T.C.B.S) agar due to fermentation of sucrose.

Biochemical identification showed that all 118 isolates had characteristic biochemical reaction to be Aeromonas species, 102 A. hydrophila and 16 A. caviae where, all A. hydrophila isolates were positive for oxidase test, catalase test, indole test, Voges-Proskauer, citrate utilization, lysine decarboxylase with $\mathrm{H}_{2} \mathrm{~s}$ production, fermented glucose, mannitol, sucrose and lactose, but they were negative for methyl red, and urease tests. Meanwhile, all A. caviae were positive for oxidase test, catalase test, methyl red test, citrate utilization, lysine decarboxylase without $\mathrm{H}_{2} \mathrm{~S}$ production, fermented glucose and mannitol, but they were negative for sucrose and lactose fermentation, Voges-Proskauer and urease tests.

Pseudomonas isolates are Gram-negative, straight or slightly curved rods. They grew well and showed large, flat, spreading and irregular colonies with greenish-blue coloration on the culture with a characteristic fruity, grapelike odour of aminoacetophenone (Ps. aeruginosa) and yellowish colonies (Ps. fluorescens) on nutrient agar. Large, pale colonies on MacConkey's agar (unable to utilize lactose) with greenish-blue pigment superimposed. Red colonies on Brilliant green agar, indicative of an alkaline reaction. Red colonies on XLD agar, no $\mathrm{H}_{2} \mathrm{~S}$ and no fermentation of sucrose and lactose sugars. Yellowish green colonies Ps. fluorescens and bluish green colonies Ps. aeruginosa on Pseudomonas agar. Small and smooth with blue-green pigmented colonies, Ps. aeruginosa on Pseudomonas Cetrimide agar.

Biochemical identification showed that all 43 isolates had characteristic biochemical reaction to be Pseudomonas species, 29 Ps. aeruginosa and 14 Ps. fluorescens where, all Ps. aeruginosa isolates were positive for oxidase test, catalase test, citrate utilization, urease test, lysine decarboxylase without $\mathrm{H}_{2} \mathrm{~S}$ production, fermented glucose and mannitol but they were negative for sucrose and lactose fermentation, indole, Voges-Proskauer and methyl red tests. Meanwhile, all Ps. fluorescens were positive for oxidase test, catalase test, citrate utilization, urease test, lysine decarboxylase without $\mathrm{H}_{2} \mathrm{~S}$ production, fermented mannitol but they were negative for glucose, sucrose and lactose fermentation, indole, Voges-Proskauer and methyl red tests

Table 1 Prevalence of positive samples for Aeromonas and Pseudomonas species isolation among examined 250 Nile tilapia (O. niloticus) fish

\begin{tabular}{|c|c|c|c|c|c|c|c|c|}
\hline \multirow{3}{*}{$\begin{array}{l}\text { No. of } \\
\text { examine } \\
\text { d lesion } \\
\text { samples }\end{array}$} & \multirow{3}{*}{ 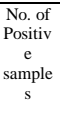 } & \multicolumn{2}{|c|}{$\begin{array}{c}\text { Positive } \\
\text { percentage }\end{array}$} & \multicolumn{3}{|c|}{ No. of single pure culture } & \multirow{2}{*}{\multicolumn{2}{|c|}{$\begin{array}{c}\text { No. of mixed } \\
\text { culture }\end{array}$}} \\
\hline & & $\% *$ & $\% *$ & & omonas & Pseudomonas & & \\
\hline & & & & No & $\begin{array}{l}{ }_{\%}{ }^{\mathrm{s} p * *} \\
{ }_{*}\end{array}$ & No $\begin{array}{c}{ }^{\text {spp }} \\
\%_{* * *}^{* *} \\
*\end{array}$ & No & $\begin{array}{c}\% * * \\
*\end{array}$ \\
\hline 445 & 128 & 51. & 28.8 & 85 & 66.4 & 7.8 & 33 & 25.8 \\
\hline
\end{tabular}

*Percentage in relation to number of examined fish samples (250).**Percentage in relation to no. of lesion samples (445). ***Percentage in relation to no. of positive samples (128)

Table 2 Prevalence and distribution of Aeromonas strains isolated from examined lesion samples

\begin{tabular}{|c|c|c|c|c|c|c|c|c|}
\hline \multirow{2}{*}{$\begin{array}{l}\text { Aeromonas } \\
\text { species } \\
\text { lesion } \\
\text { samples }\end{array}$} & \multicolumn{3}{|c|}{ A. hydrophila } & \multicolumn{3}{|c|}{ A. caviae } & \multicolumn{2}{|c|}{ Total } \\
\hline & No. & $\% *$ & $\% * *$ & No. & $\% *$ & $\% * *$ & No. & $\% * *$ \\
\hline Muscle & 29 & 28.4 & 24.6 & 7 & 43.8 & 5.9 & 36 & 30.5 \\
\hline Liver & 25 & 24.5 & 21.2 & 4 & 25.0 & 3.4 & 29 & 24.6 \\
\hline Kidney & 23 & 22.6 & 19.5 & 3 & 18.7 & 2.5 & 26 & 22.0 \\
\hline Intestine & 22 & 21.6 & 18.6 & 2 & 12.5 & 1.7 & 24 & 20.3 \\
\hline Spleen & 3 & 2.9 & 2.5 & 0 & 0.0 & 0.0 & 3 & 2.5 \\
\hline Total & 102 & 100.0 & 86.4 & 16 & 100.0 & 13.6 & 118 & \\
\hline
\end{tabular}

*Percentage in relation to number of each Aeromonas species isolated (102 and 16). ***ercentage in relation to total number of isolated Aeromonas species (118) 
Table 3. Prevalence and distribution of Pseudomonas species isolated from examined samples

\begin{tabular}{ccccccccc}
\hline $\begin{array}{c}\text { Pseudomonas species } \\
\text { lesion samples }\end{array}$ & \multicolumn{3}{c}{ Ps. aeruginosa } & \multicolumn{3}{c}{ Ps. fluorescens } & \multicolumn{3}{c}{ Total } \\
& & $\%^{*}$ & $\%^{* *}$ & No. & $\%^{*}$ & $\%^{* *}$ & No. & $\%^{* *}$ \\
\hline Muscle & 11 & 37.9 & 25.6 & 3 & 21.4 & 7.0 & 14 & 32.6 \\
Liver & 7 & 24.1 & 16.3 & 5 & 35.7 & 11.6 & 12 & 27.9 \\
Kidney & 5 & 17.2 & 11.6 & 4 & 28.6 & 9.3 & 9 & 20.9 \\
Intestine & 6 & 20.7 & 13.9 & 2 & 14.3 & 4.7 & 8 & 18.6 \\
Spleen & 0 & 0.0 & 0.0 & 0 & 0.0 & 0.0 & 0 & 0.0 \\
Total & 29 & & 67.4 & 14 & & 32.6 & 43 & 100.0 \\
\hline *ercentage in relation to number of each Pseudomonas species isolated (29 and 14).
\end{tabular}

***ercentage in relation to total number of isolated Pseudomonas species (43)

\begin{tabular}{|c|c|c|c|c|c|c|c|c|c|}
\hline \multirow[t]{2}{*}{ Antimicrobial agents } & & \multirow[t]{2}{*}{$\begin{array}{c}\text { Disk } \\
\text { concentrations }\end{array}$} & \multicolumn{2}{|c|}{ Sensitive } & \multicolumn{2}{|c|}{$\begin{array}{c}\text { Intermediat } \\
\mathrm{e}\end{array}$} & \multicolumn{2}{|c|}{ Resistant } & \multirow[t]{2}{*}{ AA } \\
\hline & & & No. & $\%$ & No. & $\%$ & No. & $\%$ & \\
\hline Amoxicillin & AMX/25 & $25 \mu \mathrm{g}$ & 6 & 5.1 & 11 & 9.3 & 101 & 85.6 & $\mathrm{R}$ \\
\hline Ampicillin & AM10 & $10 \mu \mathrm{g}$ & 0 & 0.0 & 2 & 1.7 & 116 & 98.3 & $\mathrm{R}$ \\
\hline Cefotaxime & $\mathrm{CTX} / 30$ & $30 \mu \mathrm{g}$ & 5 & 4.2 & 12 & 10.2 & 101 & 85.6 & $\mathrm{R}$ \\
\hline Ciprofloxacin & $\mathrm{CIP} / 5$ & $5 \mu \mathrm{g}$ & 96 & 81.4 & 15 & 12.7 & 7 & 5.9 & S \\
\hline Florphenicol & $\mathrm{FFC} / 30$ & $30 \mu \mathrm{g}$ & 90 & 76.3 & 15 & 12.7 & 13 & 11.0 & S \\
\hline Gentamicin & $\mathrm{CN} / 10$ & $10 \mu \mathrm{g}$ & 95 & 80.5 & 14 & 11.9 & 9 & 7.6 & S \\
\hline Meropenem & MEM & $10 \mu \mathrm{g}$ & 98 & 83.0 & 16 & 13.6 & 4 & 3.4 & S \\
\hline Methicillin & ME5 & $5 \mu \mathrm{g}$ & 2 & 1.7 & 0 & 0.0 & 116 & 98.3 & $\mathrm{R}$ \\
\hline Norfloxacin & $\mathrm{NOR} / 10$ & $10 \mu \mathrm{g}$ & 96 & 81.4 & 13 & 11.0 & 9 & 7.6 & S \\
\hline Oxacillin & oX1 & $1 \mu \mathrm{g}$ & 0 & 0.0 & 3 & 2.5 & 115 & 97.5 & $\mathrm{R}$ \\
\hline Oxytetracycline & $\mathrm{T} / 30$ & $30 \mu \mathrm{g}$ & 5 & 4.2 & 15 & 12.7 & 98 & 83.1 & $\mathrm{R}$ \\
\hline Penicillin-G & P10 & $10 \mathrm{u}$ & 0 & 0.0 & 3 & 2.5 & 115 & 97.5 & $\mathrm{R}$ \\
\hline Streptomycin & $\mathrm{S} / 10$ & $10 \mu \mathrm{g}$ & 4 & 3.4 & 17 & 14.4 & 97 & 82.2 & $\mathrm{R}$ \\
\hline Trimethoprim/ Sulphamethoxazol & $\mathrm{SXT} / 25$ & $(1.25 / 23.75) \mu \mathrm{g}$ & 17 & 14.4 & 63 & 53.4 & 38 & 32.2 & IS \\
\hline \multicolumn{10}{|c|}{ No.: Number of isolates. AA: Antibiogram activity. \%: Percentage in relation to total number of isolates (118) } \\
\hline & Ditrie & st for isolated $\mathrm{F}$ & aton & nas $\mathrm{s}$ & & & & & \\
\hline \multirow[t]{2}{*}{ Antimicrobial agents } & & \multirow[t]{2}{*}{$\begin{array}{c}\text { Disk } \\
\text { concentrations }\end{array}$} & \multicolumn{2}{|c|}{ Sensitive } & \multicolumn{2}{|c|}{ Intermediate } & \multicolumn{2}{|c|}{ Resistant } & AA \\
\hline & & & No. & $\%$ & No. & $\%$ & No. & $\%$ & \\
\hline Amoxicillin & AMX/25 & $25 \mu \mathrm{g}$ & 1 & 2.3 & 3 & 7.0 & 39 & 90.7 & $\mathrm{R}$ \\
\hline Ampicillin & AM10 & $10 \mu \mathrm{g}$ & 0 & 0.0 & 3 & 7.0 & 40 & 93.0 & $\mathrm{R}$ \\
\hline Cefotaxime & CTX/30 & $30 \mu \mathrm{g}$ & 3 & 7.0 & 4 & 9.3 & 36 & 83.7 & $\mathrm{R}$ \\
\hline Ciprofloxacin & $\mathrm{CIP} / 5$ & $5 \mu \mathrm{g}$ & 31 & 72.1 & 8 & 18.6 & 4 & 9.3 & S \\
\hline Florphenicol & $\mathrm{FFC} / 30$ & $30 \mu \mathrm{g}$ & 29 & 67.4 & 8 & 18.6 & 6 & 14.0 & S \\
\hline Gentamicin & $\mathrm{CN} / 10$ & $10 \mu \mathrm{g}$ & 33 & 76.7 & 7 & 16.3 & 3 & 7.0 & $\mathrm{~S}$ \\
\hline Meropenem & MEM & $10 \mu \mathrm{g}$ & 35 & 81.4 & 6 & 14.0 & 2 & 4.6 & S \\
\hline Methicillin & ME5 & $5 \mu \mathrm{g}$ & 3 & 7.0 & 0 & 0.0 & 40 & 93.0 & $\mathrm{R}$ \\
\hline Norfloxacin & NOR/10 & $10 \mu \mathrm{g}$ & 32 & 74.4 & 8 & 18.6 & 3 & 7.0 & $\mathrm{~S}$ \\
\hline Oxacillin & oX1 & $1 \mu \mathrm{g}$ & 1 & 2.3 & 3 & 7.0 & 39 & 90.7 & $\mathrm{R}$ \\
\hline Oxytetracycline & $\mathrm{T} / 30$ & $30 \mu \mathrm{g}$ & 5 & 11.6 & 28 & 65.1 & 10 & 23.3 & IS \\
\hline Penicillin-G & P10 & $10 \mathrm{u}$ & 0 & 0.0 & 3 & 7.0 & 40 & 93.0 & $\mathrm{R}$ \\
\hline Streptomycin & $\mathrm{S} / 10$ & $10 \mu \mathrm{g}$ & 4 & 9.3 & 27 & 62.8 & 12 & 27.9 & IS \\
\hline Trimethoprim/ Sulphamethoxazol & $\mathrm{SXT} / 25$ & $(1.25 / 23.75) \mu \mathrm{g}$ & 5 & 11.6 & 30 & 69.8 & 8 & 18.6 & IS \\
\hline
\end{tabular}

\section{DISCUSSION}

The results of clinical and postmortem examinations of studied fish were similar to that reported by Loch and Faisal (2010), Kumar and Ramulu (2013), Hanna et al. (2014), Noor El- Deen et al. (2014), and Abd El Tawab et al. (2016). The prevalence of Aeromonas and Pseudomonas species isolation (Table 1) revealed that, 128 out of 250 examined fish $(51.2 \%)$ were positive for their isolation, where 95 (74.2\%) were positive with pure single cultures, 85 Aeromonas spp. (66.4\%) and 10 Pseudomonas spp. (7.8\%) as well as $33(25.8 \%)$ mixed ones. These results came in accordance with that obtained by El- Dien et al. (2010), Shayo et al. (2012), Abd El Tawab et al. (2016) and Abd El Tawab et al. (2017). The results of bacteriological examination of examined fish lesion samples revealed that, a total of 161 Aeromonas and Pseudomonas species, 118 Aeromonas and 43 Pseudomonas species were isolated from muscle, liver, kidney, intestine and spleen lesion samples with numbers of 50, 41, 35, 32 and 3, respectively. Nearly similar results were recorded by El-Hady and Samy (2011), Hanna et al. (2014), Ibrahim- Lamis (2015) and Maarouf et al. (2017). Regarding to Aeromonas species, the recorded 
results in (Table 2) cleared that, $118(73.3 \%)$ Aeromonas species were isolated from examined samples, $102 A$. hydrophila strains $(86.4 \%)$ and 16 A. caviae strains (13.6\%). They were isolated mostly from muscle lesion samples 36 (30.5\%) (A. hydrophila $24.6 \%$ and A. caviae $5.9 \%$ ), followed by liver samples 29 (24.6\%) (A. hydrophila $21.2 \%$ and $A$. caviae $3.4 \%)$, then kidney samples $26(22.0 \%)$ (A. hydrophila $19.5 \%$ and A. caviae $2.5 \%)$, intestine $24(20.3 \%)$ (A. hydrophila $18.6 \%$ and A. caviae $1.7 \%$ ) and spleen samples $3(2.5 \%)$ that was $A$. hydrophila only. These results agree with those of Mohamed et al. (2006), Mahdy (2007), Ibrahim- Lamis (2015), Abd El Tawab et al. (2017) and Sayed (2017).

Meanwhile, disagreed with others who recorded lower incidence, El-Dien et al. (2010) and Noor El- Deen et al. (2014). Meanwhile, for Pseudomonas species, the obtained results (Table 3) revealed that, 43 Pseudomonas species were isolated from examined samples, 29 Ps. aeruginosa strains $(67.4 \%)$ and 14 Ps. fluorescens strains (32.6\%). They were mostly isolated from muscle lesion samples 14 (32.6\%) (Ps. aeruginosa $25.6 \%$ and Ps. fluorescens $7.0 \%$ ) followed by liver samples 12 (27.9\%) (Ps. aeruginosa $16.3 \%$ and $P$ s. fluorescens $11.6 \%$ ) then kidney samples $9(20.9 \%)$ (Ps. aeruginosa $11.6 \%$ and $P$ s. fluorescens $9.3 \% \%$ ) and 8 intestine lesion samples (18.6\%) (Ps. aeruginosa $13.9 \%$ and Ps. fluorescens $4.7 \%$ ) but both Pseudomonas species failed to be isolated from spleen samples. Nearly similar results were recorded by Eissa et al. (2010), Khalil et al. (2010), ElHady and Samy (2011), Hanna et al. (2014) and Abd El Tawab et al. (2016).

The morphological characteristics of the colonies, Gram staining and the biochemical profile of both Aeromonas and Pseudomonas species isolated such as the fermentation of certain sugars or enzymatic reaction as protease, lipase and extracellular pigmentation production were similar to those previously reported (Jayavignesh et al., 2011; Markey et al., 2013; Panda et al., 2013; Hanna et al., 2014; Abdel-HaqFatma El- Zahraa, 2018).

The results of in vitro sensitivity tests for 118 isolated Aeromonas strains (Table 4) revealed that they were highly sensitive to meropenem followed by ciprofloxacin, norfloxacin, gentamycin and florphenicol. Meanwhile, they were intermediate sensitive to trimethoprim/ sulphamethoxazol. Moreover, they were highly resistant for ampicillin and methicillin followed by oxacillin, penicillinG, amoxicillin, cefotaxime, oxytetracycline and streptomycin. Nearly similar results were recorded by Kore et al. (2014), Ibrahim- Lamis (2015), Didugu et al. (2016) and Abd El Tawab et al. (2017). In addition, the results of in vitro sensitivity tests for 43 isolated Pseudomonas strains (Table 5) appeared that, they were highly sensitive to meropenem followed by gentamycin, norfloxacin, ciprofloxacin and florphenicol. Meanwhile, they were intermediate sensitive to trimethoprim/sulphamethoxazol; oxytetracycline and streptomycin. In contrast, they were highly resistant for ampicillin, methicillin and penicillin-G followed by amoxicillin, oxacillin and cefotaxime. Nearly similar results were recorded by El-Hady and Samy (2011), Hanna et al. (2014), Roy et al. (2014), Abd El Tawab et al. (2016) and Abdel-Haq-Fatma El-Zahraa (2018). The recorded results are of serious concern as these drugs, especially $\beta$-lactam antibiotics, are still considered the most recommended for the treatment of bacterial infections in fish, animals and human. However, their efficiency has greatly deteriorated due to the production of $\beta$-lactamases by resistant bacterial strains.

\section{CONCULOSION}

It could be concluded that, Aeromonas and Pseudomonas species specially, A. hydrophila, A. caviae, Ps. aeruginosa and $P$ s. fluorescens strains are important pathogens causes ulcer type disease with ulcerative and septicemic syndrome among fish, they are sensitive to meropenem, ciprofloxacin, norfloxacin, gentamycin and florphenicol, can be used for treatment of these cases.

\section{REFERENCES}

1. Abd El Tawab, A.A.; Maarouf, A.A. and Ahmed, Nesma, M.G. (2016): Detection of Virulence factors of Pseudomonas species isolated from fresh water fish by PCR. Benha Vet. Med. J., 30 (1): 199-207.

2. Abd El Tawab, A.A.; Maarouf, A.A.; El Hofy, Fatma,I.; Salim, Amany, O. and and El-Mougy.E.A. (2017a): Molecular studies on antibiotic resistant genes of Aeromonas species isolated from fish. Nature and Science, 15(12): 90-97.

3. Abd El Tawab, A.A.; Maarouf, A.A.; El Hofy, Fatma,I. and and El-Mougy.E.A.(2017b): Detection of some virulence genes in A. hydrophila and A. caviae isolated from fresh water fishes at Qalubia Governorate. Benha Vet. Med. J., 33(2): 489503.

4. Abdel-Hadi, Y.M.; Z.M. El-Bouhy and A.S. Diab (2008): Prevalence of some bacterial agents affecting the gills of some cultured fishes in Egypt. Proceedings of the 30th Malaysian Symposium on Microbiology, August 16-19, 2008, Kuantan, Malaysia.

5. Abdel-Haq, Fatma El-Zahraa, M.M. (2018): Control of pathogenic bacteria by antibacterial products produced by Lactic acid bacteria. Master Degree of Science in Botany (Microbiology) Zagazig University Faculty of Science.

6. Chopra, A.K. and Houston, C.W. (1999). Enterotoxins in Aeromonas- associated gastroenteritis. Microbes Infect 1, 1129-1137.

7. Didugu, H.; Krishnaiah, N.; Rao, Madhava, T. and Ramanipushpa, R.N.(2016): Antibiogram of Aeromonas species isolated from livestock products. International Journal of Science, Environment and Technology, 5(2): 475 - 478.

8. Eissa, N.M.E.; Abou El-Ghiet, E.N.; Shahen, A.A.and Abbas, A.(2010): Characterization of Pseudomonas Species Isolated from Tilapia "Oreochromis niloticus" in Qaroun and Wadi-ElRayan Lakes. Egypt Global Veterinaria ,5 (2): 116-121.

9. El-Dien, W.M. S., Enas, M. S., Hanan, M. T. E., Salah, M.A (2010): prevalence of Aeromonas hydrophila and Yarsinia entrocolitica in some sea food sold In Sharkia Governorate markets and the effect of heat treatment on their viabilities Bulletin of animal health and production in Africa, 57 (3):191197.

10. El-Hady, M.A. and Samy, A.A.(2011): Molecular Typing of Pseudomonas Species Isolated from Some Cultured Fishes in Egypt. Global Veterinaria., 7 (6): 576-580.

11. Hanna, M.I.; El-Hady, M.A .; Hanaa,A.A.; Elmeadawy, S.A and Kenwy, A.M. (2014): Contribution on Pseudomonas aeruginosa infection in African Catfish (Clarias gariepinus) Research Journal of Pharmaceutical, Biological and Chemical Sciences, 5 (5): 575-588.

12. Ibrahim, Lamis, S.A. (2015): Studies on virulent and antibiotic resistant genes of Aeromonas species isolated from fish. Ph.D. (Bacteriology, Immunology and Mycology), Fac. Vet. Med., Suez Canal University.

13. Jayavignesh, V.; Sendesh K. K. and Abhijith D. Bhat (2011): Biochemical characterization and cytotoxicity of the A. hydrophila isolated from Catfish Arch. Appl. Sci. Res., 3 (3): $85-93$. 
14. Khalil, S.A.; Khalil, R.H.; Saad, T.T.and Safaa, M.H.(2010):Studies on Pseudomonas Septicemia among Cultured Oreochromus niloticus. Journal of the Arabian Aquaculture Society, 5(1):55-64.

15. Konemann, E.; Allen, S.; Janda, W.; Schreckenberger, C. and Winn, W. (1997): Color Atlas and Textbook of Diagnostic Microbiology. Fifth Edition. Lippincott, Philadelphia, New York.

16. Kore, PK.; Kolhe, RP.; Deshpande, PD.; Bhong, CD.; Jadha, SN.;Nagargoje, AB.; Jagtap, UV.; Dhandore, CV.; Tumlam, UM; Pawar,PD and Khansnis, MW. (2014):Prevalence of ant imicrobial resistant Aeromonas in chicken and fish washings. Afr. J. Microbiol. Res., 8(27) : 2609- 2615

17. Kumar, M.P. and Ramulu, K.S.(2013): Presumptive and definitive identification of Pseudomonas from infected Pangasius hypophthalmus in culture ponds of West Godavari and Krishna. J. Microbiol. Biotech. Res., 3 (3): 41-45.

18. Loch T.P. and Faisal M. (2010): "Infection of Lake Whitefish (Coregonus clupeaformis) with Motile Aeromonas spp. in the Laurentian Great Lakes" Journal of Great Lakes Research 36 (suppl. 1): 6-12.

19. Maarouf, A.A.; Nassif, Marionette, Z.; Selim, Amany O. and Ali, Enas A.(2017): Bacteriological and molecular studies on Aeromonas organisms isolated from some species of fish and its public health hazards. Animal Health Research J. 5 (4 B): 549-559.

20. Mahdy, W.G. (2007): Studies on the use of polymerase chain reaction in diagnosis of bacterial infection caused by Aeromonas hydrophila in fish. M. V. Sc. Thesis. Fac. Vet. Med. Zagazig Univ.

21. Markey, B.K.; Leonard, F.C. ; Archambault, M. ;Cullinane, A. and Maguire, D. (2013): Clinical Veterinary Microbiology . Second edition. MOSBY. Elsevier Ltd. Edinburgh London New York Oxford Philadelphia St Louis Sydney Toronto.

22. Mavrodi, D.V.; Bonsall, R.F.; Delaney, S.M.; Soule, M.J.; Phillips, G. and Thomashow, L.S.(2001): Functional analysis of genes for biosynthesis of pyocyanine and phenazine-1carboxamide from Pseudomonas aeruginosa PAO1.J. Bacteriol., 183(21): 6454-6465.
23. Mohamed, L. A., Osman, K. M., El seedy, S. and Soliman, W. (2006): Isolation and characterization of Aeromonas species and Pseudomonas fluorescence from freshwater fishes. International Conference, Research Division, National Research Center. Pp. 219-229.

24. Noor El Deen, A.E.; Sohad, M. Dorgham; Azza, H.M. Hassa $\mathrm{n}$ and Hakim,A.S. (2014). Studies on Aeromonas hydrophila n cultured Oreochromis

niloticus at Kafr El Sheikh governorate, Egypt with reference to

histopathological alterations in some vital organs. World Jour nal offish and Marine Sciences 6 (3): 233-240.

25. Panda, S.; Bandyopadhyay, P.K. and Chatterjee, S.N. (2013): Characterization of Pseudomonas aeruginosa PB112 (JN996498) isolated from infected Labeo bata (Hamilton) by 16S rRNA gene sequence analysis and fatty acid methyl ester (FAME) analysis. African Journal of Biotechnology , 12(4): 400-405.

26. Rabaan, A. A.; Gryllos, I.; Tomas, J. M. and Shaw, J. G. (2001): Motility and the polar flagellum are required for Aeromonas caviae adherence to HEp-2 cells. J. Infect. Immun., 69: 4257-4267.

27. Roy, R.P.; Bahadur, M. and Sudip- Barat, S. (2014): Studies on antibiotic resistant activity of Pseudomonas spp., isolated from fresh water loach, Lepidocephalichthys guntea and water sample of river Lotchka, Darjeeling, India.J. 35(1) : 237-241.

28. Sayed, M.O.K. (2017): Contribution toward prevention of motile Aeromonas septicemia in some freshwater fishes. M. V. Sc. Thesis. Fac. Vet. Med. (Fish Diseases and Management), Beni-Suef Univ.

29. Shayo, S. D.; Mwita, C. J. and Hosea, K.M. (2012): Virulence of Pseudomonas and Aeromonas bacteria recovered from Oreochromis niloticus (Perege) from Mtera hydropower Dam Tanzania Annals of Biological Research, 3 (11): 5157-5161.

30. Stratev, D. ; Daskalov, H. and Vashin, I.(2015) Characterization and determination of antimicrobial resistance of $\beta$-haemolytic Aeromonas spp. isolated from common carp (Cyprinus carpio L.). Revue Méd. Vét., 166 (1-2): 54-61 